\title{
PLATYSTELE PAMELAE (ORCHIDACEAE: PLEUROTHALLIDINAE), A NEW SPECIES FROM ECUADOR
}

\author{
Luis E. Baquero R. ${ }^{1,2,3,4}$ \& KiLian Zuchan ${ }^{2}$
}

${ }^{1}$ Carrera de Ingeniería Agroindustrial y Alimentos. Facultad de Ingeniería y Ciencias Agropecuarias. Universidad de Las Américas, Calle José Queri, Quito 170137, Pichincha, Ecuador

${ }^{2}$ Jardín Botánico de Quito, Quito, 170135, Pichincha, Ecuador

${ }^{3}$ Instituto Nacional de Biodiversidad, Quito, Pichincha, Ecuador

${ }^{4}$ Author for correspondence: lbaquero@hotmail.com

\begin{abstract}
A new species of Platystele from the cloud forests of Northern Ecuador is described and illustrated. Platystele pamelae is compared to $P$. alucitae, a species that is overall similar and has been found growing sympatrically. The morphology of the leaves, the shape of the sepals and the intense sulphur-colored oblong lip, easily separate P. pamelae from P. alucitae and all other species in Platystele. Taxonomical and ecological notes are given.
\end{abstract}

Key words: Ecuador, new species, Platystele pamelae, Pleurothallidinae

Introduction. The genus Platystele Schltr. (Orchidaceae: Pleurothallidinae) currently contains 111 species (Karremans 2016, Jost \& Iturralde 2017). As initially proposed by Rudolf Schlechter in 1910, the species of this genus are characterized by small plants without pseudobulbs with very small to tiny flowers. The description was emended by Carlyle Luer in 1990, indicating also that most species exhibit caespitous habits, a ramicaul shorter than the leaf and free sepals. Certain species exhibit some of the smallest flowers in the orchid family such as $P$. jungermannioides (Schltr.) Garay, P. enervis Luer, P. ornata Garay, P. tica Karremans \& Bogarín or P. lycopodioides Luer \& Hirtz. The most recognizable trait of this taxon is the short, bilobed column and the firmly fixed lip to the rudimentary column-foot of the flowers (Luer 1990), and a pair of pollinia that lack caudicles and are united by a drop-like viscidium (Karremans et al. 2016).

The genus has a wide geographical distribution along the Americas, extending from Mexico, in the north, to Bolivia and Brazil in the south (Luer 1990). Ecuador, with 61 species, is considered the center of diversity for the genus (Jørgensen \& León-Yánez 1999, Dodson 2003, Dodson 2004, Ulloa \& Neill 2005, Luer 2010, Baumbach 2011, Neill \& Ulloa 2011, Jost \& Iturralde 2017). The north-west of Ecuador, around the village Maldonado, in the northern Carchi province, many species of Platystele can be found such as the widely distributed $P$. caudatisepala (C.Schweinf.) Garay and $P$. examen-culicum Luer, growing close to locally restricted, apparently endemic species like $P$. delhierroi Luer \& Hirtz, P. hirtzii Luer and P. adelphe Luer \& Hirtz. A recently discovered species from that area is described here (Fig.1).

Platystele pamelae Baquero \& Zuchan, sp. nov. (Fig. $1-3)$.

TYPE: Ecuador. Carchi: between Chical y El Carmen, $0^{\circ} 49^{\prime} 96.0^{\prime \prime} \mathrm{N} 78^{\circ} 12^{\prime} 78.9^{\prime \prime} \mathrm{W}, 1836 \mathrm{~m}$, collected by Luis Baquero et al. on February 8, 2016, LB 3043 (holotype, QCNE).

Diagnosis. Platystele pamelae is similar to $P$. alucitae Luer from which it differs by the elliptical (vs. narrowly elliptic-obovate), three-ribbed (vs. not ribbed) leaves, and the ligulate (vs. ovate), centrally sulcated (vs. lightly excavate centrally) lip.

Plant very small, epiphytic, densely caespitose, erect, up to $1.6 \mathrm{~cm}$ tall. Roots basal, slender, to $0.5 \mathrm{~mm}$ in diameter. Ramicauls terete, very short enclosed by two or three ribbed, imbricating sheaths. Leaf erect, coriaceous, petiolate, elliptical, to 7-16 $\mathrm{mm}$ long, 


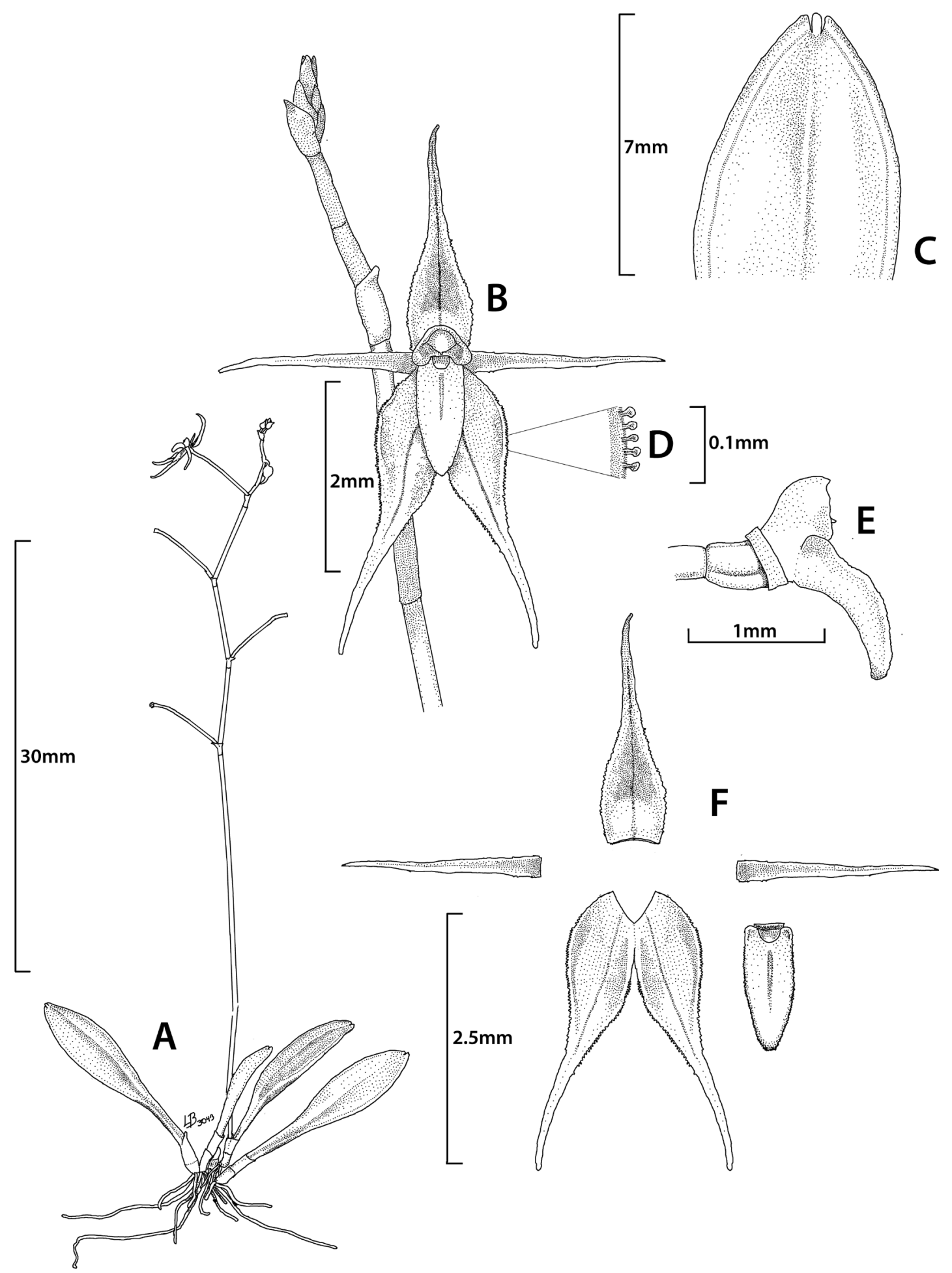

Figure 1. Platystele pamelae Baquero \& Zuchan. A. Habit. B. Flower close-up. C. Leaf detail. D. margin of the lip close-up.

E. Column and lip, lateral view. F. Disected flower. (Drawn from the holotype.) Illustration by Luis Baquero. 


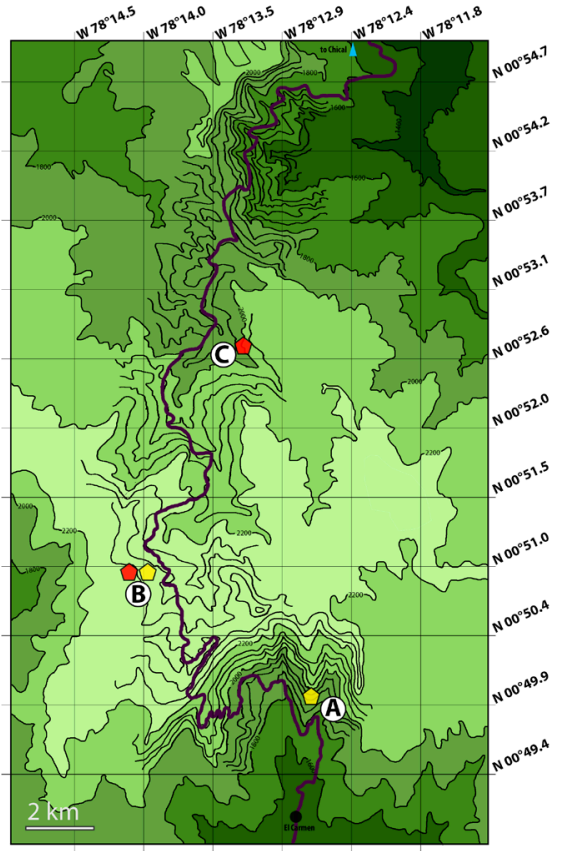

\section{Legend}

Platystele alucitae

$\triangle$ Platystele pamelae

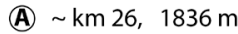

(B) $\sim \mathrm{km} \mathrm{19,2384} \mathrm{m}$

(C) $\sim \mathrm{km} \mathrm{14}, 1978 \mathrm{~m}$

Roadway El Carmen and Chical

FIgURE 2. Roadmap between El Carmen and Chical including the places where Platystele pamelae (yellow) and $P$. alucitae (red) were found.

including a petiole $2-9 \mathrm{~mm}$ long, conduplicate, with two ribs parallel and close to the entire margin of the blade, mucronate apex, with an apiculus nested inside the leaf, 2.0-2.8 mm wide. Inflorescence loose, erect to suberect, terete, flexuous, distichous, successively few-flowered raceme with up to two translucent saffron-colored flowers, raceme up to $115 \mathrm{~mm}$ long; borne by a slender peduncle $11-25 \mathrm{~mm}$ long arising laterally from the ramicaul; floral bracts thin, acute, conduplicate, to $1 \mathrm{~mm}$ long; slightly deflexed pedicels $2.5-5.5 \times 0.18 \mathrm{~mm}$. Ovary smooth, short, ridged with 6 ridges, to $0.45 \times 0.30 \mathrm{~mm}$. Sepals translucent saffron-colored sometimes centrally suffused with lilac and intense sulphur-colored at the apex with clavate cilia at the margins, one veined, elliptical; dorsal sepal ovate and concave in the lower half or third, 1.6-2.6 mm long, with an acuminate apex, 0.6-

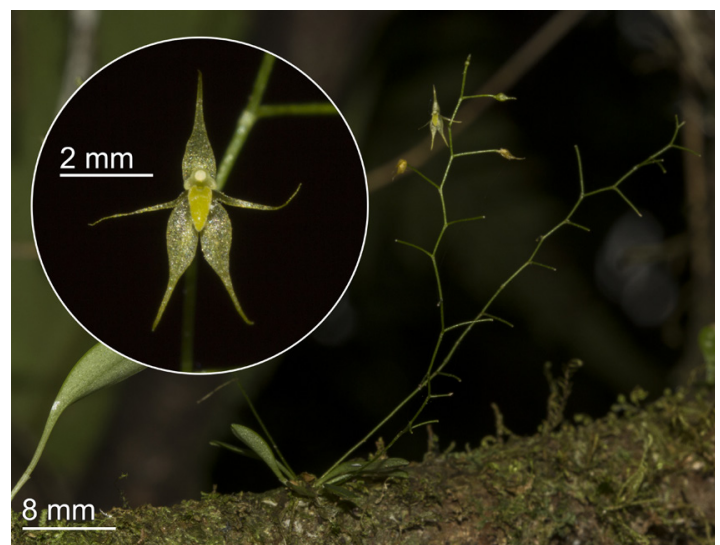

FIgURE 3. Habit of Platystele pamelae in situ with close-up on the flower. Photograph by L. Baquero.

$0.7 \mathrm{~mm}$ wide above the base; lateral sepals ovate with an acuminate apex, $2.7-2.8 \times 0.6-0.7 \mathrm{~mm}$; connate at the base to $0.4 \mathrm{~mm}$. Petals translucent saffron-colored transitioning into intense sulphur-colored towards the apex, shortly ciliated at the margins; narrowly linear, filamentous, acute, long-acuminate, 1.7-2.4 $\times 0.2 \mathrm{~mm}$. Lip sulphur-colored, thick, with short capitate cells, ligulate, obtuse, apex slightly deflexed, $0.80-0.90 \times$ $0.37-0.45 \mathrm{~mm}$, the disc with a centrally longitudinal sulcus beginning at the middle of the lip, sulcus 0.15 $0.25 \mathrm{~mm}$ long, centrally horizontally curved down, the base truncate enclosing a circular shiny glenion, glenion $0.1-0.2 \mathrm{~mm}$ wide; fixed to the column-foot. Column straw-colored sometimes suffused with lilac, stout, semiterete, $0.5-0.6 \times 0.6 \mathrm{~mm}$, the stigma bilobed, the foot rudimentary. Pollinia not observed. Fruit a capsule, globous to short elliptical, six-ribbed; seeds not observed.

Eponymy: The name was chosen to honor Pamela Yela, daughter of don Héctor Yela (Park Ranger of the Dracula Reserve in the Carchi Province), who was responsible of getting her father interested in orchids.

Other studied Material: Flowers in alcohol from cultivated plants of the Jardín Botánico de Quito, collected the type locallity, LB 3104 (paratype, QCNE).

Distribution: Known from cloud forests of two locations at $\mathrm{km} 26$ and at $\mathrm{km} 19$ (from where the holotype comes) of the road Chical-El Carmen between $1836 \mathrm{~m}$ and $2310 \mathrm{~m}$ in elevation of Carchi Province, Ecuador. 
Habitat and Ecology: Many new species of orchids have been found in recent years along the road of Chical-El Carmen in the Carchi Province of Ecuador. This road is marked at each kilometer, from north to south. From south to north, this $29 \mathrm{~km}$ long road starts in El Carmen, where the road climbs abruptly to the highest point of the road at around $2400 \mathrm{~m}$ close to $\mathrm{km} 22$, then over the next $11 \mathrm{~km}$ gradually goes down to $1900 \mathrm{~m}$ and then descends drastically in the further course until reaching Chical at $1000 \mathrm{~m}$ in elevation, on the border with Colombia (Fig. 2).

From south to north, the road climbs abruptly to nearly $1900 \mathrm{~m}$ at $\mathrm{km} \mathrm{26}$, where the first population of $P$. pamelae was discovered, growing sympatrically with other species of the subtribe Pleurothallidinae in a remaining cloud forest (holotype, Fig. 2-A). Then, the road keeps climbing to the highest elevation at 2384 $\mathrm{m}$ in elevation (close to $\mathrm{km} \mathrm{22}$ ) where primary cloud forest, rich in Dracula species, can be found. Past the highest point, at $\mathrm{km} 19$ P. pamelae and P. alucitae were found growing sympatrically (Fig. 2-B). Further north, the road gradually descends to $1900 \mathrm{~m}$. Here, extremely moist cloud forests remain close to $\mathrm{km} 14$ where $P$. alucitae also grows among species of Andinia Luer (Luer), Brachionidium Lindl., Dracula Luer, Lepanthes Sw., Masdevallia Ruiz \& Pav., Porroglossum Schltr., Pleurothallis R.Br., Scaphosepalum Pfitzer, Specklinia Lindl. and Stelis Sw., but P. pamelae is not found (Fig. 2-C). Afterwards, the road descends more abruptly and is ending in Chical at $1000 \mathrm{~m}$ in elevation.

This road has been explored by the orchid specialists team of Ecominga Foundation since the road was first opened in 2008. P. pamelae was always found growing on thin branches thickly covered by moss and lichens.

The strong resemblance and shared habitat with Platystele alucitae could indicate shared ancestry of those two species. Both species prefer similar environments. Morphologically both species share long inflorescences (Fig. 3), which, in case of $P$. alucitae, can reach up to $18 \mathrm{~cm}$ (Luer 1990), a translucent ovate dorsal sepal, which exhibits a concave indention at the lower third and the connate, narrowly ovate lateral sepals (Fig. 4).

Nonetheless both species can be easily distinguished by the features of the leaves, inflorescence and flowers. Platystele pamelae and $P$. alucitae both show elliptical to narrowly ellipticalobovate leaves. The ribs in these two species is what distinguishes them from each other. While $P$. alucitae has a typical conduplicate leaf with one central rib, $P$. pamelae has three-ribbed leaves, of which the outer two ribs are located closely to the entire margin of the leaf. Another distinguishing trait can be found in the slightly deflexed pedicels in the inflorescence of $P$. pamelae, while those of $P$. alucitae are rather linear. The sepals with clavate cilia around the margins can be found in $P$. pamelae, which are similar to those in $P$. baqueroi Jost \& Iturralde, is another trait which distinguishes $P$. pamelae from $P$. alucitae. Finally the ligulate, centrally deep sulcated and slightly deflexed, sulfur-colored lip distinguishes $P$. pamelae from all other species in the genus Platystele, and clearly from the most similar species $P$. alucitae, which has an ovate, obtuse, lightly excavate centrally lip. Platystele stevensonii Luer shows the most similar lip to $P$. pamelae in the genus, but which is just shallowly sulcate and does not exhibit any curvature. The differences in the form of lip and glenion between $P$. pamelae and $P$. alucitae might indicate a reproductive specialization, especially useful considering the sympatrical growth.

Materials and methods. The plants of Platystele alucitae and P. pamelae were collected by the team of the Botanical Garden of Quito with the Environmental Research Permit No. 008-2016-IC-FLO-DNB/MA issued by the Enviromental ministry of Ecuador (Ministerio del Ambiente del Ecuador).

These plants are cultivated by the Botanical Garden of Quito, where they, together with plants in alcohol, ( $L B 3112,3113$, type locality), where used for morphological comparisons.

Due to the minute size of plant and flowers, measurements were largely conducted on the basis of photos with a specific $10 \mathrm{~mm}$ ruler and the open source, image-processing program ImageJ (National Institutes of Health) downloaded from https://imagej. nih.gov/ (Lind 2012).

The material was photographed with the ruler at the same focal distance. The photos were opened in Image $\mathrm{J}$ and $10 \mathrm{~mm}$ of the ruler were set as a scale (Fig. 4). The program calculates the number of pixels to the given unit, with which measurements were made. 


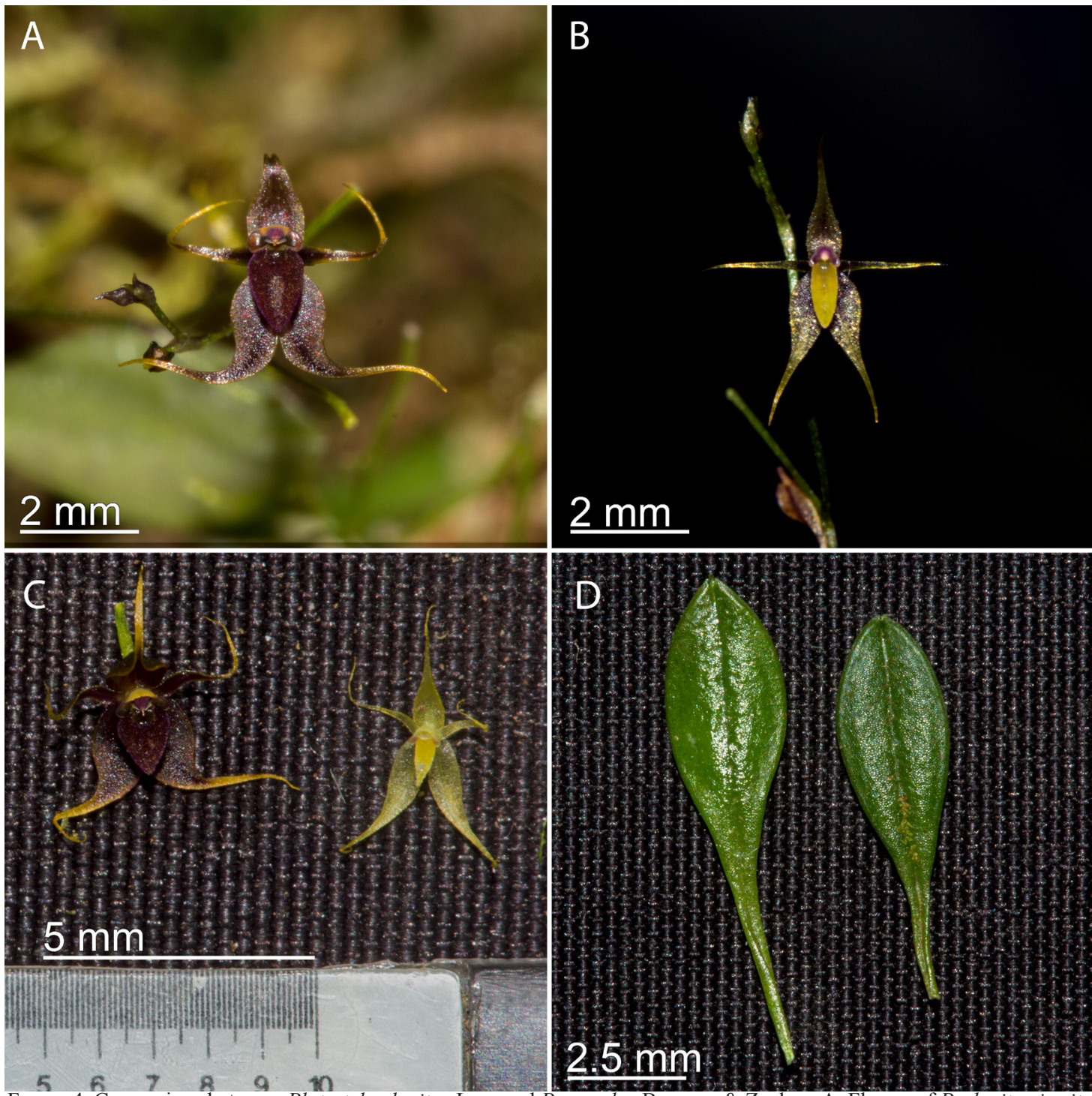

Figure 4. Comparison between Platystele alucitae Luer and P. pamelae Baquero \& Zuchan. A. Flower of $P$. alucitae in situ

B. Flower of $P$. pamelae in situ from the same region. C. Direct comparison of the flowers of $P$. alucitae (left) and $P$. pamelae (right). D. Comparison of leaves from P. alucitae (left) and P. pamelae (right).

AcKnOWLEDGEMENTS. We acknowledge Universidad de Las Americas (UDLA) for funding research on orchids in Ecuador. The Ministerio del Ambiente del Ecuador is acknowledged for issuing the Environmental Research Permit No. 008-2016-IC-FLO-DNB/MA. We also want to thank don Héctor Yela for his year-long support in the research and conservation of orchids from the Carchi province and as a recognition of his conservation efforts this species honors his daughter by carrying her name. Finally to the Ecominga Foundation for working on the conservation of orchids in situ by preserving forests before they are cut down. Finally, we are grateful to the Editor and the anonymous reviewers for suggestions on the manuscript.

\section{LITERATURE CITED}

Baumbach, N. (2011). Pleurothallis rubella Luer 1977. Die Orchidee (Hamburg), 62(3), 230-231.

Dodson, C. H. (2003). Native Ecuadorian Orchids IV: Oncidium - Restrepiopsis. Quito, Ecuador: Imprenta Mariscal.

LANKESTERIANA 17(2). 2017. (C) Universidad de Costa Rica, 2017. 
Dodson, C. H. (2004). Native Ecuadorian Orchids V: Rodriguezia-Zygosepalum. Quito, Ecuador: Imprenta Mariscal.

Jost, L. \& Iturralde, G.A. (2017). A showy new Platystele (Pleurothallidinae: Orchidaceae) from Northwest Ecuador. Lankesteriana, 17(1), 55-60.

Jørgensen, P. M. \& Leon-Yanez, S. (Eds.). (1999). Catálogo de las plantas vasculares del Ecuador, Volume 75. St. Louis: Missouri Botanical Garden Press.

Karremans, A. P., Albertazzi, F. J., Bakker, F. T., Bogarin, D., Eurlings, M. C., Pridgeon, A., Pupulin, F. \& Gravendeel, B. (2016). Phylogenetic reassessment of Specklinia and its allied genera in the Pleurothallidinae (Orchidaceae). Phytotaxa, 272(1), 1-36.

Karremans, A. P. (2016). Genera Pleurothallidinarum: an updated phylogenetic overview of Pleurothallidinae. Lankesteriana, 16(2), 219-241.

Lind, R. (2012). Open Source Software in Life Science Research: Practical Solutions in the Pharmaceutical Industry and Beyond. Abington, Cambridge UK: Woodhead Publishing Ltd.
Luer, C. A. (1990). Icones Pleurothallidinarum. VII. Systematics of Platystele (Orchidaceae). Monographs in Systematic Botany from the Missouri Botanical Garden, 38, 1-132.

Luer, C. A. (1994). Icones Pleurothallidinarum. XI. Systematics of Lepanthes, subgenus Brachycladium, and Pleurothallis, subgenus Aenigma, subgenus Elongatia, subgenus Kraenzlinella; Addenda to Dracula, Lepanthopsis, Myoxanthus, Platystele, Porroglossum, and Trisetella. Monographs in Systematic Botany from the Missouri Botanical Garden, 52, 121.

Luer, C. A. (2010). Icones Pleurothallidinarum XXXI: Lepanthes of Bolivia. Systematics of Octomeria species north and west of Brazil. Monographs in Systematic Botany from the Missouri Botanical Garden, 120, 145.

Neill, D. A. \& Ulloa, C. U. (2011). Adiciones a la flora del Ecuador: segundo suplemento: 2005-2010 (p.126). Quito, Ecuador: Fundación Jatun Sacha.

Ulloa, C. U. \& Neill, D. A. (2005). Cinco años de adiciones a la flora del Ecuador: 1999-2004 (p.42). St. Louis: Missouri Botanical Garden Press. 